\title{
THE EFFECTS OF MULTIENZYME PREPARATION ON PRODUCTION RESULTS OF FATTENING CHICKS FED RYE-BASED DIETS
}

\author{
VLASTA ŠERMAN, Ž. MIKULEC, NORA MAS. F. DUMANOVSKI \\ Department of Animal Nutrition, Faculty of Veterinary Medicine. University of Zagreb. \\ and POLJOPRERADA d. d.. Zagreb, Croatia
}

Received April 8, 1997

Accepted November 4, 1997

\begin{abstract}
Šerman V., Ž. Mikulec, N. Mas, F. Dumanovski: The Effects of Multienzyme Preparation on Production Results of Fattening Chicks fed Rye-based Diets. Acta vet. Brno 1997. 66:147-154.

The effects of multienzyme preparation Polizym ${ }^{\circledR}$ (amylase, protease, B-glucanase, Bglucosidase, cellulase) on production results of chick fed diets with different levels of rye (up to $60 \%$ ) was investigated ( 280 Ross chicks, fattening period of 42 days). Chicks were divided into seven groups and held in cage-system with feed and water ad libitum. Over the first three weeks, all groups were fed starter for fattening chicks and afterwards a finisher. The control group was fed commercial maize-based mixtures. In diet for experimental groups maize was partially substituted by rye $(6 \%, 30 \%$ and $60 \%)$. Experimental mixtures were used with or without addition of Polizym ${ }^{\circledR}$. The influence of rye and added preparation on body weight gain, feed conversion rate, amount of abdominal fat and litter moisture were examined. The results indicated that $30 \%$ and $60 \%$ of rye in diets decreased body weight gain $(\mathrm{P}<0.01)$. while $6 \%$ of rye in diet increased body weight gain $(\mathrm{P}<0.01)$ when compared to the control group. Regardless of Polizym ${ }^{(3)}$ addition. higher proportions of rye (30\% and $\left.60 \%\right)$ increased the feed conversion rate and the amount of abdominal fat. Chicks fed $6 \%$ rye diet had lower feed conversion rate when compared to the control group and lower amount of abdominal fat, especially when fed with Polizym ${ }^{\circledR}$. Higher rye proportions increased faeces moisture. Polizym ${ }^{\circledR}$ had positive effects in decreasing faeces moisture only in diets with $6 \%$ of rye. Rye in diets did not cause any health problem during the investigation.
\end{abstract}

Nutrition, fattening chicks, rye, enzyme preparation Polizym ${ }^{\circledR}$. body mass gain, feed conversion, abdominal fat, litter moisture

Poultry anatomical and physiological characteristics require the use of complete feed mixtures of balanced composition, high energy value and digestibility when high productivity is expected. Since energy value of poultry feeds is an essential factor for their efficiency, energy-rich cereal grains usually make about $60 \%$ in feed mixtures. High energy value and digestibility of maize make it the most suitable grain for composing feed mixtures. For this reason, it is often not available on the market in required quantities, or the price is too high.

If maize is not available for preparing diets, other grains like barley, rye and oats, or even wheat and triticale, can be partly used as substitution. Presence of some antinutritive substances in them, such as pentosans in rye and B-glucans in barley and oats (A $n$ to $n$ i o u et al. 1981; Classen et al. 1985; Campbell et al. 1986; Hesselman and Aman 1986) affects the digestibility of the diet, and therefore their amount in a feed mixture is limited.

Numerous investigations have been carried out with the aim of determining possibilities of substituting other grains for maize in diets for poultry. Mostly used substitutes are rye and barley. The reason is their moderate price on the market and also their capability of adapting to unfavorable climatic conditions and poor soil (Koreleski 1986; Näsi 1988). 
However, the results of numerous investigations have shown unfavorable effects of cereal grains less valuable in energy, particularly rye, on poultry health and consequently their performance and productivity (Moran et al. 1970; Petters son 1987; Smulikowska and Buraczewski 1990; Richter and Ranft 1993; Lemser and Richter 1993). Using rye in feeding poultry also results in a series of technological problems, such as production of sticky droppings. This has been wellknown in poultry feeding for a long time ( $\mathrm{Halpin}$ et al. 1936; Fernandez et al. 1973; Marquardt et al. 1979; Jami et al. 1980). In laying hens, dirty eggs are frequent ( $\mathrm{Richter}$ and $\mathrm{Ranft} 1993$ ) and cleaning and disinfecting net flours and cages is more difficult.

The main reason for such unfavourable effect of rye on poultry health and production results is the presence of non-starch polysaccharides, primarily arabinoxylans and B-glucans in cell walls of the endosperm (Ant oniou and Marquardt 1981; White et al. 1983). They are of particular nutritional importance because in contact with a liquid medium in the gut they increase viscosity of the intestinal content. In this way they directly affect the digestibility and utilisation of nutrients ( $\mathrm{Grah}$ am 1991).

Adding enzymes or their mixtures to feed is one among the various ways in improving the nutritive value of rye. First results of investigations on the effect od adding enzyme preparations to feed mixtures could be found in the forties ( $\mathrm{H}$ a st in $\mathrm{g}$ s 1946). It was found that adding enzyme preparations to feed with high content of raw fiber increases the growth of chickens and feed utilisation. Bacterial as well as fungal enzyme preparations added to diets based on rye increases daily gain in body weight of chicks and improves feed conversion (Moran et al. 1969).

Since the substrates for enzyme activity are known today, it is possible, by activity of specific enzymes ( $B$-glucanase, pentosanase and others) or their mixtures, to overcome or to reduce the problems connected with the use of so-called less valuable grains in feeding poultry.

\section{Materials and Methods}

Animals and diets

The investigation was carried out on a total of 280 sexed fattening chicks of the Ross hybrid line. One-day-old chicks were weighed and selected into 7 groups ( 20 males and 20 females in each) according to their body weight. The average body weight of chicks in all the groups was equal on the first day of the trial. The chicks were kept for 42 days. All groups were kept in the same microclimatic conditions. Microclimatic conditions (temperature, relative air humidity, animal density, feeding space) throughout the investigation met the zoohygienic requirements for this line of hybrids. Health state of the chicks was checked daily.

Feed and water were provided ad libitum. In the first three weeks, the chicks were fed a starter mixture, and over the last three weeks a finisher mixture. A control group of chicks (C) was fed commercial complete feed mitures of standard composition, while the mixtures for the trial groups of chicks (E-1 to E-6) contained different shares of rye: starter and finisher mixtures used for feeding the chicks in trial groups E-1 and E-4 contained 6\% of rye, which represents $10 \%$ of maize substitution in commercial mixtures. Mixtures for trial groups E-2 and E-5 contained $30 \%$ of rye, making $50 \%$ substituted with rye (60\% of rye in the mixture). The mixtures for the trial groups E-1, E-2 and E-3 were without multienzyme preparation.

In mixtures for trial groups E-4, E-5 and E-6, the multienzyme preparation Polizym ${ }^{\circledR}$ (KRKA-Novo Mesto, Slovenia) in amounts of $0.25 \mathrm{mg} / \mathrm{kg}$ of feed $(0.025 \%)$ was added. The preparation is a powdery, stabilised mixture of enzymes amylase, protease, $B$-glucanase, $B$-glucosidase and cellulase.

The composition of the starter and finisher mixtures is shown in Table 1 and nutritive value and chemical composition in Table 2. 
Table 1

Composition of starter and finisher mixtures used in the trial

\begin{tabular}{|c|c|c|c|c|c|c|c|c|}
\hline \multirow[b]{2}{*}{ Groups } & \multicolumn{4}{|c|}{ Starter } & \multicolumn{4}{|c|}{ Finisher } \\
\hline & $\mathrm{C}$ & $\begin{array}{c}\mathrm{E} \\
1 / 4\end{array}$ & $\begin{array}{c}\mathrm{E} \\
2 / 5\end{array}$ & $\begin{array}{c}\mathrm{E} \\
3 / 6\end{array}$ & $\mathrm{C}$ & $\begin{array}{c}E \\
1 / 4\end{array}$ & $\begin{array}{c}E \\
2 / 5\end{array}$ & $\begin{array}{c}E \\
3 / 6\end{array}$ \\
\hline \multicolumn{9}{|l|}{ Compounds (\%) } \\
\hline Maize & 62.77 & 56.50 & 31.00 & - & 60.08 & 54.00 & 30.00 & - \\
\hline Rye & - & 6.20 & 31.00 & 62.00 & - & 6.00 & 30.00 & 60.00 \\
\hline Soybean meal & 14.01 & 18.33 & 11.23 & 22.00 & 29.53 & 28.99 & 19.01 & 6.80 \\
\hline Toasted soya & 13.92 & 9.43 & 17.19 & 3.00 & - & 1.20 & 11.01 & 22.48 \\
\hline Fish meal & 6.00 & 6.00 & 6.00 & 6.00 & - & - & - & - \\
\hline Gluten (maize) & - & - & - & - & 2.55 & 2.27 & 2.51 & 3.36 \\
\hline Soya oil & - & - & - & 3.50 & 3.50 & 3.50 & 3.50 & 3.50 \\
\hline$\overline{D C P}$ & 1.31 & 1.30 & 1.20 & 1.50 & 2.03 & 2.00 & 1.92 & 1.82 \\
\hline Limestone & 1.19 & 1.46 & 1.47 & 1.10 & 1.49 & 1.23 & 1.23 & 1.23 \\
\hline Salt & 0.18 & 0.18 & 0.31 & 0.30 & 0.31 & 0.31 & 0.31 & 0.31 \\
\hline Premix & 0.50 & 0.50 & 0.50 & 0.50 & 0.50 & 0.50 & 0.50 & 0.50 \\
\hline DL-Methionine & 0.11 & 0.11 & 0.10 & 0.10 & - & - & - & - \\
\hline Polizym* & - & $-1+$ & $-1+$ & $-1+$ & - & $-1+$ & $-1+$ & $-1+$ \\
\hline TOTAL & 100 & 100 & 100 & 100 & 100 & 100 & 100 & 100 \\
\hline
\end{tabular}

${ }^{*}$ Multienzyme preparation Polizym ${ }^{\circledR}$ is produced by KRKA, Novo Mesto, Slovenia. The preparation is stabilised mixture of the enzymes: amylase, protease, B-glucanase, B-glucosidase and cellulase.

Table 2

Nutritive values and chemical composition of mixtures used in the trial

\begin{tabular}{|l|c|c|c|c|c|c|c|c|}
\cline { 2 - 9 } \multicolumn{1}{c|}{} & \multicolumn{4}{c|}{ Starter } & \multicolumn{4}{c|}{ Finisher } \\
\hline Groups & $\mathrm{C}$ & $\begin{array}{c}\mathrm{E} \\
1 / 4\end{array}$ & $\begin{array}{c}\mathrm{E} \\
2 / 5\end{array}$ & $\begin{array}{c}\mathrm{E} \\
3 / 6\end{array}$ & $\mathrm{C}$ & $\begin{array}{c}\mathrm{E} \\
1 / 4\end{array}$ & $\begin{array}{c}\mathrm{E} \\
2 / 5\end{array}$ & $\begin{array}{c}\mathrm{E} \\
3 / 6\end{array}$ \\
\hline Crude protein (g.kg-1) & 210.0 & 212.1 & 213.6 & 209.0 & 200.0 & 201.2 & 200.0 & 200.0 \\
\hline Arginine (g.kg-1) & 13.3 & 13.5 & 13.6 & 13.5 & 12.6 & 12.7 & 12.5 & 12.2 \\
\hline Methionine (g.kg-1) & 5.6 & 5.5 & 5.3 & 5.0 & 4.0 & 3.9 & 3.8 & 3.7 \\
\hline Cystine (g.kg-1) & 2.9 & 3.0 & 3.2 & 3.4 & 3.0 & 3.1 & 3.3 & 3.5 \\
\hline Meth+Cys (g.kg-1) & 8.5 & 8.5 & 8.5 & 8.4 & 7.0 & 7.0 & 7.1 & 7.2 \\
\hline Lysine (g.kg-1) & 11.5 & 11.5 & 11.7 & 12.0 & 9.6 & 9.8 & 9.8 & 9.8 \\
\hline Tryptophan (g.kg-1) & 2.3 & 2.3 & 2.4 & 2.5 & 2.1 & 2.2 & 2.2 & 2.3 \\
\hline Threonine (g.kg-1) & 8.3 & 8.3 & 8.4 & 8.0 & 7.4 & 7.5 & 7.5 & 7.6 \\
\hline Crude fat (g.kg-1) & 59.8 & 50.0 & 58.5 & 59.3 & 62.4 & 63.3 & 75.9 & 90.3 \\
\hline Crude fibre (g.kg-1) & 34.0 & 35.0 & 33.3 & 34.3 & 38.0 & 38.1 & 35.6 & 32.4 \\
\hline Total minerals (g.kg-1) & 57.7 & 60.6 & 60.3 & 59.2 & 61.9 & 59.3 & 57.2 & 54.4 \\
\hline Calcium (g.kg-1) & 11.0 & 12.0 & 12.0 & 11.3 & 11.0 & 10.0 & 10.0 & 10.0 \\
\hline Phosphorus (g.kg-1) & 7.0 & 7.0 & 7.0 & 7.4 & 6.5 & 6.5 & 6.5 & 6.5 \\
\hline Natrium (g.kg-1) & 1.5 & 1.5 & 2.0 & 2.0 & 1.5 & 1.5 & 1.5 & 1.5 \\
\hline ME (MJ/kg) & 12.56 & 12.20 & 12.03 & 11.75 & 12.62 & 12.56 & 12.56 & 12.56 \\
\hline
\end{tabular}


Measuring production results

The effects of commercial mixtures and mixtures with various fractions of rye (with or without enzyme preparation Polizym ${ }^{\circledR}$ ) on final body mass, total body mass gain. feed conversion, share of abdominal fat in carcass and final body mass, droppings moisture, uniformity of the flock and health of chicks were observed.

The body mass was checked every 7 days by individual weighing of all chicks. Food consumption was recorded daily in order to determine weekly and total food conversion values.

At the end of the fattening period ( $42^{\text {nd }}$ day) 10 chicks from each group were slaughtered ( 5 males and 5 females) in order to determine abdominal fat mass.

The share of carcass in the live mass of chicks (dressing) and the share of abdominal fat in carcass were determined on the basis of body mass of live chicks which fasted for 12 hours before slaughtering. The carcass mass was measured without feathers. skin. head, neck, internal organs. lower parts of legs and abdominal fat.

The moisture of droppings was determined every 5 days by drying $\left(105^{\circ} \mathrm{C} / 24 \mathrm{~h}\right)$ an average sample $(10 \mathrm{~g})$.

Uniformity of chicks from the control and trial groups with respect to body mass was based on calculating varability coefficient. relative measure expressed in percentage.

The health condition of the chicks was assessed clinically, and from pathoanatomical findings in the dead animals. Chicks in all the groups were vaccinated in the usual way for Newcastle disease.

The significance of differences between the mean values of the parameters obtained by measurements was assessed by the Student's t-test according to S nedecor and Cochran (1967).

\section{Results}

Final body mass of chicks, total body mass gain, total consumption and conversion of food are shown in Table 3.

Table 3

Production indicators obtained in $\mathbf{4 2}$ days investigation

\begin{tabular}{|c|c|c|c|c|c|c|c|}
\hline Groups & $\mathrm{C}$ & $\mathrm{E}-1$ & $\mathrm{E}-4$ & $\mathrm{E}-2$ & $\mathrm{E}-5$ & $\mathrm{E}-3$ & E-6 \\
\hline Final body mass (g) & 1642.8 & 1738.0 & 1891.6 & 1512.8 & 1560.8 & 1087.6 & 1267.5 \\
\hline $\begin{array}{c}\text { Total average body } \\
\text { mass gain (g) }\end{array}$ & 1602.5 & 1699.2 & 1852.1 & 1473.8 & 1522.7 & 1048.7 & 1228.4 \\
\hline $\begin{array}{c}\text { Total average feed } \\
\text { consumption (kg) }\end{array}$ & 132.65 & 149.57 & 138.50 & 141.64 & 130.12 & 119.64 & 118.18 \\
\hline $\begin{array}{c}\text { Feed conversion } \\
(\mathrm{kg} / \mathrm{kg})\end{array}$ & 2.07 & 2.20 & 1.92 & 2.40 & 2.14 & 2.85 & 2.53 \\
\hline Number of chicks (n) & 40 & 40 & 39 & 40 & 40 & 40 & 38 \\
\hline
\end{tabular}

Besides the production results in Table 3 , the abdominal fat shares in the live mass and in carcass, respectively, were observed as additional indicators for evaluation of effects of rye and added Polizym ${ }^{\circledR}$ on production results of fattening chicks - Table 4.

Table 4

Average abdominal fat mass in control $(C)$ and experimental $(E)$ groups of chicks $(n=10)$

\begin{tabular}{|c|c|c|c|c|c|c|}
\hline Groups & $\begin{array}{c}\text { Live mass } \\
(\mathrm{g})\end{array}$ & Carcass $(\mathrm{g})$ & $\begin{array}{c}\text { Abdominal } \\
\text { fat }(\mathrm{g})\end{array}$ & $\begin{array}{c}\text { Dressing } \\
(\%)\end{array}$ & $\begin{array}{c}\text { Fat in } \\
\text { carcass }(\%)\end{array}$ & $\begin{array}{c}\text { Fat in live } \\
\text { mass }(\%)\end{array}$ \\
\hline C & 1603.0 & 1138.4 & 24.4 & 71.0 & 2.1 & 1.5 \\
\hline E-1 & 1660.0 & 1187.6 & 37.0 & 71.5 & 3.1 & 2.2 \\
\hline E-2 & 1574.5 & 1101.0 & 29.1 & 69.9 & 2.6 & 1.8 \\
\hline E-3 & 1120.5 & 747.7 & 21.0 & 66.7 & 2.8 & 1.9 \\
\hline E-4 & 1907.5 & 1340.8 & 36.9 & 70.1 & 2.8 & 1.9 \\
\hline E-5 & 1614.7 & 1105.3 & 30.2 & 68.5 & 2.7 & 1.9 \\
\hline E-6 & 1432.0 & 963.2 & 28.3 & 67.7 & 2.9 & 2.0 \\
\hline
\end{tabular}


One of the effects of multienzyme preparation is to overcome or at least decrease the negative effects of feeding rye with respect to wet litter and therefore the moisture of droppings was determined in all the groups of chicks - Table 5.

Table 5

Moisture of faeces $(\%)$ during the trial

\begin{tabular}{|c|c|c|c|c|c|c|c|}
\cline { 2 - 8 } \multicolumn{1}{c|}{} & \multicolumn{7}{c|}{ G r o u p s } \\
\hline Day & C & E-1 & E-4 & E-2 & E-5 & E-3 & E-6 \\
\hline 10. & 70.81 & 78.53 & 72.74 & 77.18 & 81.95 & 79.86 & 81.98 \\
\hline 15. & 76.19 & 78.20 & 78.50 & 78.81 & 79.27 & 79.29 & 76.44 \\
\hline 20. & 69.69 & 77.19 & 75.40 & 77.57 & 77.77 & 77.62 & 78.72 \\
\hline 24. & 73.33 & 75.94 & 72.54 & 77.71 & 77.27 & 78.25 & 76.18 \\
\hline 27. & 75.77 & 77.49 & 71.45 & 76.05 & 75.53 & 76.54 & 76.32 \\
\hline 30. & 75.43 & 79.33 & 70.28 & 79.50 & 75.43 & 77.46 & 74.26 \\
\hline 33. & 79.30 & 82.33 & 73.03 & 79.48 & 78.48 & 80.01 & 75.50 \\
\hline 36. & 78.03 & 78.91 & 76.05 & 79.84 & 76.66 & 78.45 & 76.26 \\
\hline Average & 74.82 & 78.49 & 73.75 & 78.27 & 77.79 & 78.44 & 76.96 \\
\hline
\end{tabular}

In order to fully understand the effect of various amounts of rye in chick diets as well as of the added enzyme preparation on the production results, uniformity of body mass in chicks in both the control and trial groups was calculated. The results are shown in Table 6 .

Table 6

Uniformity of body mass of control (C) and experimental (E) groups of chicks

\begin{tabular}{|c|c|c|c|c|}
\hline Groups & $\mathrm{n}$ & $\mathrm{x}$ & $\mathrm{s}$ & $\mathrm{CV}$ \\
\hline $\mathrm{C}$ & 40 & 1642.8 & 166.78 & 10.15 \\
\hline $\mathrm{E}-1$ & 40 & 1738.0 & 221.08 & 12.72 \\
\hline $\mathrm{E}-4$ & 39 & 1891.6 & 206.20 & 10.90 \\
\hline E-2 & 40 & 1512.8 & 215.86 & 14.27 \\
\hline E-5 & 40 & 1560.8 & 199.57 & 12.79 \\
\hline E-3 & 40 & 1087.6 & 185.72 & 17.08 \\
\hline E-6 & 38 & 1267.5 & 182.13 & 14.37 \\
\hline
\end{tabular}

$\mathrm{n}=$ number of chicks; $\mathrm{x}=$ mean value of body mass; $\mathrm{s}=$ standard deviation; $\mathrm{CV}=$ variability coefficient $(\%)$

\section{Discussion}

Effects of various shares of rye in a diet, as well as of the added Polizym ${ }^{\circledR}$ were determined on the ground of already mentioned production results of fattening chicks.

According to final body mass $(1891.6 \mathrm{~g})$, total body mass gain $(1852.1 \mathrm{~g})$ and feed conversion $(1.92 \mathrm{~kg} / \mathrm{kg})$ the best production results were achieved in chicks fed $6 \%$ of rye in a diet with Polizym ${ }^{\circledR}$ added (group E-4). On the other hand, chicks fed the same diet without any preparation added (group E-1) achieved a slightly lower final body mass 
(1738.0 g), poorer total body mass gain ( $1699.2 \mathrm{~g})$ and poorer feed conversion $(2.20 \mathrm{~kg} / \mathrm{kg})$. However, the chicks from the trial groups had better results than the chicks from the control group (C) fed standard commercial mixtures based on maize. They achieved poorer total body mass gain (1602.5 g) and consequently lower final body mass (1642.8 g) than the chicks of the trial groups.

The production results obtained in other groups were in negative correlation with the share of rye in the diet. The increase of the share of rye in the diet to $30 \%$ and $60 \%$ caused considerable deterioration in the body mass gain and feed conversion. The final body mass of chicks fed on the diet containing 30\% (E-2: $1512.8 \mathrm{~g}$ ) and 60\% (E-3: $1087.6 \mathrm{~g})$ of rye without multienzyme preparation was by $7.9 \%$ and $22.8 \%$ lower in comparison with the control group ( $\mathrm{C}: 1642.8 \mathrm{~g})$. These differences were highly significant $(\mathrm{P}=0.01)$. A decrease in production results with higher share of rye in the diet $(25 \%)$ was also observed by M o r a et al. (1970).

Addition of enzymes in our experiment reduced the negative effect of rye on body mass gain. The final body mass of chicks fed on $6 \%, 30 \%$, and $60 \%$ of rye in the diet with the multienzyme preparation added was by $8.9 \%, 3.2 \%$ and $16.5 \%$, respectively, higher than the final body mass of equally fed chicks without the multienzyme preparation.

The best feed conversion was found in chicks fed $6 \%$ rye in the diet and enzyme preparation added (group E-4). Feed conversion in this group was by $7.2 \%$ better in comparison to the control group. An increase of the share of rye correlated with increase in feed conversion value. The addition of enzyme preparation had a positive effect on feed conversion. Such a positive effect of enzyme preparations mixed into diets for fattening chicks on feed conversion was also observed by Pe t t e r s s o n et al. (1990). In the research carried out by Richter et al. (1990) a better effect on improving feed conversion was obtained by the preparation containing B-glucanase and pentosanase.

At the end of the fattening period ( $42^{\text {nd }}$ day) measuring of the abdominal fat (average of 5 male and 5 female chicks from each group) showed that rye in the a diet increased the percentage of fat in live mass and carcass in relation to the control group regardless to addition of Polizym ${ }^{\circledR}$ - Table 4 .

Average faeces moisture in our investigation was lowest in the chicks fed on $6 \%$ of rye in the diet and with enzyme preparation added (group E-4), even slightly lower than in the control group (C). Addition of Polizym ${ }^{\circledR}$ to diets containing $30 \%$ and $60 \%$ of rye did not show any remarkable effect on reducing faeces moisture. However, the results of research carried out by $\mathrm{Jackisch}$ and Jer och (1990) indicated that the enzyme preparation Bergazym H (cellulase, arabinoxylanase. $\beta$-glucanase, $\alpha$-amylase, protease) could improve faeces consistency of fattening chicks fed $31 \%$ of rye in the diet as well. The reason for this difference is most probably the effect of the enzyme arabinoxylanase which Polizym ${ }^{\circledR}$ does not contain. This was also confirmed by the research of Petters on et al. (1990) proving that the combination of enzymes $\beta$-glucanase and arabinoxylanase in the preparation is more efficient in reducing occurrence of watery faeces in the chicks fed on rye than B-glucanase itself.

Increasing the share of rye in the diet for fattening chicks in our investigation increased the body mass variability in all the trial groups. The lowest variability coefficient was found in the control group (C) while in the chicks fed on $6 \%$ of rye and added enzyme preparation (E-4) it was slightly higher. In the groups of chicks fed without enzyme preparation, the variability increased with the increase of the share of rye in the diet. Enzyme preparation added into the diet with $30 \%$ and $60 \%$ of rye showed a favourable effect on body mass uniformity.

Checking the health condition of chicks during the 42 days of investigation as well as the results of pathoanatomical examination of dead chicks did not indicate a connection between 
the addition of rye to the diet and dying. Bone deformities due to rye in the diet were not observed in any of the experimental groups. Conversely, Smulikowska and Buraczewski (1990) observed in their research not only growth depression, but also frequent occurrence of bone deformities in chicks fed diets containing $40 \%$ of rye.

The investigation can be summarized by the conclusion that $6 \%$ rye in the diet resulted in higher final body mass, a better feed conversion and a smaller amount of moisture in the faeces when compared to the control group of chicks, particularly when multienzyme preparation Polizym ${ }^{\circledR}$ was added to the diet. Higher amounts of rye in the diet $(30 \%$ and $60 \%$ ) adversely affected production results regardless of the addition of enzyme preparation Polizym ${ }^{\circledR}$.

\section{Účinek multienzymatického preparátu na produkci výkrmových brojlerů krmených potravou obsahující žito}

Účinek multienzymatického přípravku Polizymu (amyláza, proteáza, ß-glukanáza, ß-glykosidáza, celuláza) na produkci výkrmových brojlerů (plemeno Ross, doba krmení 42 dnů) krmených dietou s rủzným množstvím žita (až do $60 \%$ ). Kuřata byla rozdělena do 7 skupin a chována $v$ klecích $\mathrm{s}$ krmivem a vodou ad libitum. Během prvních 3 týdnů byla všechna kuřata krmena startovací směsí pro výkrmové brojlery a posléze směsí. Kontrolní skupina byla krmena komerční směsí s kukuřicí. U experimentální skupiny byla kukuřice částečně nahrazena žitem $(6 \%, 30 \%$ a $60 \%)$. Experimentální směs byla použita s Polizymem i bez něj. Výzkum spočíval ve stanovení vlivu množství žita a přidaného Polizymu na přirůstky, ve stanovení stupně konverze krmiva a množství abdominálního tuku včetně vlhkosti podestýlky. V této studii jsme dokázali, že ve srovnání s kontrolní skupinou se tělesná váha při objemu 30 a $60 \%$ žita v krmivu snížila $(P<0,01)$ a při množství $6 \%$ žita v krmivu se tělesná váha zvýšila $(P>0,01)$. Kuřata krmená dietou s $6 \%$ obsahem žita vykazovala ve srovnání s kontrolní skupinou nižší stupeň konverze krmiva a abdominálního tuku, zejména po přidáni Polizymu. Vyšší množství žita v krmivu bylo př́ǐcinou zvýšené vlhkosti fécés. Šestiprocentní obsah žita měl pozitívní vliv na snížení vlhkosti výkalů. Obsah žita v krmivu nevyvolal během výykumu žádné zdravotni problémy.

\section{References}

ANTONIOU, T., MARQUARDT, R. R. 1981: Influence of rye pentosans on the growth of chicks. Poultry Sci. 60: $1898-1904$

ANTONIOU, T., MARQUARDT, R. R., CANSFIELD, P. E. 1981: Isolation, partial characterisation and antinutritional activity of a factor (pentosans) in rye grain. J. Agric. Food Chem. 28: 1240-1247

CAMBELL. G. L.. CLASSEN, H. L., BALLANCE, G. M. 1986: Gamma-irradiation treatment of cereal grains for chick diets. J. Nutr. 116: 560-569

CLASSEN, H. L.. CAMPBELL, G. L., ROSSNAGEL, B. G., BHATTY, R., REICHERT, R. D. 1985: Studies on the use of the hulless barley in chicks diets: deleterious effect and methods of alleviation. Can. J. Anim. Sci. 65: $725-733$

FERNANDEZ, R., LUCAS, E., McGINNIS, J. 1973: Fractionation of chick growth depressing factor from rye. Poultry Sci. 52: 2252-2259

GRAHAM. H. 1991: The physical and chemical constitution of foods: Effect on carbohydrate digestion. In vitro digestion for pigs and poultry. C. A. B. Wallingford, Oxon. pp. 35-44

HALPIN. J. G., HOLMES, C. E., HART, E. B. 1936: Rye as a feed for poultry. Poultry Sci. 15: 3-8

HASTINGS. W. H. 1946: Enzyme supplements to poultry feeds. Poultry Sci. 25: 584-586

HESSELMAN, K.. AMAN, P. 1986: The effect of beta-glucanase on the utilisation of starch and nitrogen by broiler chicks fed on barley of low- or high-viscosity. Anim. Feed Sci. Techn. 15: 83-93

JACKISCH, B., JEROCH, H. 1990: Studies for improvement of the feed value of the fattening feed for broilers rich in rye by enzyme supplements. Arch. Anim. Nutr. 40: 1109-1118

JAMI, M. S.. PUBOLS, M. H., McGINNIS, J. 1980: Effect of gamma irradiation on the physicochemical properties of rye. Poultry Sci. 59: 253-257

KORELESKI. J. 1986: Results of preliminary experiments on rye in feeding of chicks and laying hens in Poland. 10. Kollegium zur Geflügelernährung. Leipzig. pp. 50-58 
LEMSER, A., RICHTER, G. 1993: Rye as a component of a poultry diet. 3. Rye in layer diets for chickens and pullets. Arch. Anim. Nutr. 44: 139-146

MARQUARDT, R. R.. WARD, A. T., MISIR, R. 1979: The retention of nutrients by chicks feed rye diets supplemented with amino acids and penicillin supplementation. Poultry Sci. 58: 631-640

MORAN, E. T., LALL, S. P., SUMMERS, J. D. 1969: The feeding value of rye for the growing chick: Effect of enzyme supplements. antibiotics, autoclaving and geographical area of production. Poultry Sci. 48: 939-949

MORAN, E. T.. LALL. S. P.. SUMMERS, J. D. 1970: Altering the proportion of rye to maize in the grain fraction of practical broiler rations: effect on live performance, litter moisture, dressing yield, and carcass quality. Brit. Poultry Sci. 11: 147-152

NÄSI, M. 1988: Enzyme supplementation of laying hen diet based on barley and oats. Biotechnology in the Feed Industry. Proceedings of Alltech's 4th Annual Symposium. pp. 199-204

PETTERSSON. D. 1987: Substitution of maize with different levels of wheat, triticale or rye in diet for broiler chickens. Swed. J. Agric. Res. 17: 57-62

PETTERSSON, D., GRAHAM, H., AMAN, P. 1990: Enzyme supplementation of broiler chicken diets based on cereals with endosperm cell walls rich in arabinoxylans or mixed-linked B-glucans. Anim. Prod. 51:201-207

RICHTER. G., RANFT. U., PETZOLD, A., SCHWARTZE, J. 1990: Influence of enzyme preparations on the performance of broilers fed on rye. Arch. Anim. Nutr. 40: 951-958

RICHTER, G.. RANFT. U. 1993: Rye as a component in poultry diet. 2. Fattening turkeys. Arch. Anim. Nutr. 42: $45-54$

RICHTER, G., LEMSER. A., SITTE, E. 1993: Rye in poultry mixtures. 9th European Symposium of Poultry Nutrition, Jelenia Gora. Poland. pp. 332-336

SMULIKOWSKA, S.. BURACZEWSKI, S. 1990: Influence of rye on production results, carcass dressing percentage and bone mineralisation of broiler chickens. Bull. Sci. Feed Industry 29: 59-70

SNEDECOR, G., COCHRAN, W. G. 1967: Statistical Methods. Iowa University Press, Ames WHITE, B. W., BIRD. H. R., SUNDE, M. L., MARLETT, J. A. 1983: Viscosity of B-glucan as a factor in the enzymatic improvement of barley for chicks. Poultry Sci. 62: 853

Address for correspondence:

Prof. dr. sci. Vlasta Šrman

Faculty of Veterinary Medicine

Heinzelova 55

10000 Zagreb, Croatia

Phone: (385) 2390270

Fax: (385) 1214697 